\title{
THE LEVEL AND STRUCTURE OF SLAVE PRICES ON CUBAN PLANTATIONS IN THE MID-NINETEENTH CENTURY: SOME COMPARATIVE PERSPECTIVES*
}

\author{
MANUEL MORENO FRAGINALS \\ UNESCO
}

HERBERT S. KLEIN

Columbia University

STANLEY L. ENGERMAN

Universidad del Desarrollo and University of Chicago

Originally published in Spanish:

Revista de Historia Económica 1, 1, 1983, pp. 97-120

Keywords: Cuba, Slavery

JEL Codes: N36, O54

Palabras clave: Cuba, esclavitud

\footnotetext{
* All the Cuban documentation used in this article is in the National Archive of Cuba, Fondo "Escribanias" (Judiciales). It was selected by a group of historical studies led by Dr. Manuel R. Moreno Fraginals. The initial phase of data processing was carried out at the Centro de Computación del Poder Popular de la Ciudad de La Habana, under the technical direction of Ivan Lejardi, whose collabouration and valuable suggestions we greatly appreciate. Tito Diaz also provided technical assistance. The subsequent processing of the data was carried out by the co-authors, at the calculation centers of the Universities of Columbia and Rochester, with the help of James Irwin. Portions of this work were funded by the National Science Foundation. We also wish to thank David Eltis and Rebecca Scott for their comments on a first draft of this article.
} 
In the contemporary resurgence of interest in slavery and slave societies in America, the use of price data has been one of the fundamental sources that historians and economists have used to analyse the nature of the slave economy. After the work of Conrad and Meyer, scholars have attempted to interpret the behaviour of the planters, as well as their expectations and beliefs, through a detailed analysis of the pattern of changes in slave prices over time. Despite its importance, surprisingly little systematic price data has been collected, other than the crucial series produced for the United States slave markets. Only recently have series been generated in a systematic way for the other major slave societies, such as Brazil and the British West Indies. Several important and secondary slave economies in the rest of the New World still lack this information. In this context, the main area that has been least studied is the important slave economy of Cuba. Although it has been the third largest such system in the western world and the second longest-running regime, the existing data on Cuba is extremely limited. The objective of this article is to offer a first systematic analysis of the prices of Cuban slaves in the vital period of growth of plantations, that is, in the mid-nineteenth century.

In our analysis we will attempt to determine the price differences between not only male and female slaves, but also between African and native Creole slaves, as well as between skilled and unskilled slave workers. When interpreting these data, we will also compare them with the materials that have survived in some other slave regimes to determine the unique and common features of the slave regime of plantations in nineteenth century Cuba.

The sources of this study are the price and demographic data on slaves on Cuban plantations collected systematically by Manuel Moreno Fraginals during many years of work in the public and private archives of Cuba. ${ }^{\mathrm{T}}$ This extraordinary collection covers the prices of slaves on Cuban plantations from the beginning of the 18th century until the eve of abolition in the late nineteenth century. From this extensive collection we have decided to select the most complete set of price data, consisting of the values of more than 4,200 slaves from 14 plantations that cover the years between 1856 and $1863,{ }^{2}$ because it was not only the most complete data for this period, but it was also an important time in the development of slavery in Cuba and in other parts of the New World.

\footnotetext{
${ }^{1}$ For an earlier use of these data, see Moreno Fraginals (1977), pp. 187-201.

2 There are two years listed for two of the plantations and we have considered them as independent observations. There is a possibility of duplication for less than 10 percent of all slaves.
} 
II

There are several sources to study the prices of Cuban slaves, including the newspaper announcement of sales and the thousands of purchase contracts that are kept in the National and municipal archives. Obviously, not all have the same degree of reliability. In this work we have only used the following primary sources:

1. The prices set in the valuation of the Cuban sugar plantations that were pending adjudication for various reasons, such as inheritance disputes and debt collection.

2. The prices fixed in the insurance policies of the sugar planters.

In both cases, the method used to set the prices of slaves was similar. In the adjudication cases, the litigating parties designated, by mutual agreement, a group of experts (generally three) who were always people with long experience in the business of slaves and sugar. The five individuals then proceeded to make a list of all slaves. Given the high costs of these procedures (all the examples come from large plantations) and the powerful conflicting interests, the prices were neither higher nor lower than the market values. In the case of insurance policies, the price was set by three people: a representative of the insurance company, a doctor and the owner of the slaves. If the contracting parties did not reach an agreement on prices (the doctor's opinion was purely technical), no policy was issued, since the insurance premiums were based on the price of the slaves. In both sources, a detailed description of each slave was given for identification purposes to avoid possible later frauds (for example, the substitution of a slave by one of lesser value).

We have preferred these two sources to others for various reasons. They were prepared using the same method of pricing slaves. When prices were set by people familiar with the slave market and supervised by interested parties and contenders, they tended to be accurate, as conflicts of interest prevented them from being above or below market value. In addition, as described in the appendix, they offered additional information on each slave and on the distinctive features that explained the unusual prices.

With regard to the period of time covered, we have used data in the years 1856, 1859, 1861 and 1863. In Cuba, slavery lasted until 1886; but at the end of 1867 it became known that the Spanish Government was preparing an abolition law, according to which compensation would be paid to the slave owners. ${ }^{3}$ The expected abolition with compensation law was never drafted, but in 1870 the Moret Law was approved, which freed slaves

${ }^{3}$ On the background to the abolition of Cuban slavery, see Corwin (1967). 
over sixty years of age, as well as those born to slave mothers from that date (among other clauses). But, for the statistical purposes that concern us here, it is important to note that all Cuban sources relative to post-1868 slave populations are age biased. ${ }^{4}$

Given the sources of these data and the possibility that there are certain biases, we have carried out some tests of the gender division of the set of observations used and of the sugar plantations in western Cuba that appear in the 1861 census. ${ }^{5}$ Within our sample of plantations, the slave population was made up of $60.6 \%$ of men, while in the total census of sugar plantations in the region where the sample plantations were located there was 64.0 men per 100 women. ${ }^{6}$ As might be expected, in the sample the ratio between slaves and slaves of African origin (2.18) was considerably higher than that of Creoles (which was almost 1.0 exactly). In the best ages, the proportion between men and women of African origin (2.63) was higher than that of Creoles (0.99). The higher proportion of African males at the best ages relative to that of the oldest ages suggests either that African women lived longer than men, or that the sex composition of the slave trade varied from beginning to end of the nineteenth century. ${ }^{7}$

\footnotetext{
${ }^{4}$ Under the expected law of 1867, slaves under the age of sixty would be subject to guardianship (similar to the apprenticeships in the English abolition law). Those over the age of sixty would automatically be released. For this reason, a census of slaves was carried out and it was pointed out that, by law, the Spanish government did not recognize any slave who was not included in that census. Accordingly, the owner of each slave was given a cedula for each slave, in which the general data for their identification were recorded. But, since the slave owners assumed that the compensation would be related to the age of the slaves and since they feared that the slaves would be given freedom after the age of sixty, when they were still useful, these are generally described at ages much lower than the real ones, especially in the case of those who were over fifty years old. Unfortunately, the census has been lost, but its general data are preserved and even a simple analysis shows its inaccuracy.

${ }^{5}$ El Centro de Estadística (1864).

${ }^{6}$ Examination of the 1861 Census Cedulas and the accounting books of approximately five plantations that year indicates that the census omitted children aged zero to five, whose sex ratio was probably close to equality. This omission, perhaps due to the fear of the landowners that the census would be used for tax purposes and their desire to omit slaves who were not working, could explain the meaning of the difference in the text and would mean that the sex ratio of our sample could be more accurate than that of the published census.
}

${ }^{7}$ There may have been some variations in the sex ratio of Cuban slave imports throughout the 19th century. Klein (1979) p. 223 estimates that more than 70 percent of the Africans who arrived in Havana between 1790 and 1820 were male. Various unpublished data extracted from F084 (and provided by David Eltis) indicate that, in the period 1854-1863, males accounted for 75 percent of the creoles was 1.33 , reflecting the importance of African imports in the Cuban expansion and the apparently low fertility of the female slaves. It should be noted, however, that the estimates made by the Cuban Andres Iduate, who has collected data on the expeditions of slaves captured in Cuba between 1820 and 1870, indicate that in the 1840s the proportion was 60 percent of men and that in the 1850s there were some expeditions with more women than 
We have also compared the prices of slaves (of the best ages) with those recorded in various primary sources and the estimates derived from those sources by other historians. ${ }^{8}$ The prices obtained from the plantations are consistent, both in level and in variations, with those obtained from other sources.

\section{III}

In Cuba slavery presents a rather unusual pattern of development compared to that of the other major slave areas of the Caribbean and other parts of the New World. ${ }^{9}$ Colonized very early, Cuba did not greatly expand its use of slave labour and its sugar economy until the end of the 18th century. In addition to starting very late, Cuba was also the last area of the Caribbean to abolish slavery, since the final emancipation only occurred two years before the last emancipation of the New World, that of Brazil in 1888. However, during this period, Cuba rose meteorically as a sugar producer, aided by the disappearance of slavery in the British West Indies in 1834 and, later, by the reduction of British tariffs in the late 1840s, as well as by expansion of the American market. Cuba's sugar production increased dramatically after the $1820 \mathrm{~s}$, and by the end of the $1850 \mathrm{~s}$ its level was almost six times the average level of 1825-1829. At the beginning of the 1870 s, Cuban sugar production was almost ten times that of the end of the 1820s (see Table 1). At that time, Cuba was the largest producer of cane sugar in the world.

This increase in sugar production was achieved by dedicating to it the slave labour of the island that was previously used in urban areas and in the production of tobacco and coffee. Probably more important was the expansion of slave imports from Africa in the mid-nineteenth century. Despite its illegal nature and the constant British pressure to end this trade,

men. Therefore, it seems that variations in the pattern of slave imports cannot explain the different proportions by sex in the different age groups. In the British West Indies, the mortality of African men was higher than that of women, and the disproportionate sex ratio of slave imports did not prevent the sex ratio from being more equal among the African population at the beginning of the century xix. See, for example, Higman, (1976), pp. 71-80.

${ }^{8}$ Among the contemporary comments examined are those of the Boletin Comercial de La Habana and letters from Juan Poey, owner of the Las Canas Plantation. See also Aimes (1907), p. 267; Ely (1961), pp. 121-123 and Her Majesty's Commissary Judge to Lord J. Russell (Extract), February 5, 1861, reprinted in Irish University Press Series Slave Trade, vol. 47 (Section 2), pp. 7-8.

9 The most complete recent analysis of slavery in Cuba is that of Moreno Fraginals (1978) and (1976). See also Ortiz (1975); Klein (1967); Knight (1970); Scott (1981); Aimes (1907); Ortiz (1947), and Guerra y Sanchez (1964). 
Cuban slave imports continue to be large and, in fact, reached a maximum in the period after $1850 .{ }^{10}$ By the time the slave trade in Brazil was definitively closed, for the second half of the century, Cuba was the only important area in the New World that still received slaves from Africa (see Table 2). In the period 1856-1863, despite constant attempts to end trade, the imports of slaves from Africa reached an annual average of approximately 13,000 , reaching a maximum of 25,000 in $1859 .{ }^{11}$

In this article we will analyse the price data of slaves from Cuba from the period 1856-1863, years in which the last large imports of slaves from Africa took place. During this period, sugar production for the European and American markets grew considerably (as Table 1 shows), while sugar prices fluctuated around a generally constant level. ${ }^{12}$ At this time, Cuba produced around a third of the world production of cane sugar. Slave imports were high, and in the 1852-1861 decade some 130,000 accounted for approximately 35 percent of the number of slaves recorded in the 1861 population census. ${ }^{13}$ In addition to the importation of slaves, contracted labour was also being imported for plantations from China and Yucatan, and in the period 1853-1861 at least 40,000 Chinese arrived in Cuba. ${ }^{14}$

\footnotetext{
${ }^{10}$ See Murray (1980). Also see Eltis, "The Direction and Fluctuations of the Transatlantic Slave Trade,1844-1867", (unpublished).

${ }^{11}$ Also see the data presented in Curtin (1969), chap. 2; Eltis (1979), pp. 273-301; Klein, (1979) pp. 209-227 and Aimes (1907) p. 269.

${ }^{12}$ For London sugar prices in this period, see Deerr, (1949-1950), p. 531. Wholesale prices for sugar in the United States are found in U. S. Bureau of the Census (1975), p. 209. There are data on the unit values of sugar imported into the United States in the United States, Department of the Treasury, Bureau of Statistics, "The World's Sugar Production and Consumption," in the Monthly Summary of Commerce and Finance, January 1902, contained in the Chamber of Representatives, 57 Congress, 1. doc session. num. 15, part 7), pp. 2691-2692. In the publications of Willett and Gray, sugar merchants of New York, there is an important series of sugar prices.

${ }^{13}$ Estimates of the slave population for 1861 are found in Noticias estadísticas de la isla de Cuba en 1862. For an analysis of the Cuban population censuses see Kiple (1976).

${ }^{14}$ The total number of Chinese who arrived before 1861 was approximately 40,000, according to the Boletin de Migración of that time. The 1861 census shows a Chinese population of 34,828 , a figure that seems quite reasonable considering the biased sex ratio (almost all males), the high death rate and the return of some who had ended their contract period. Yucatan's labour import was quite low; the 1861 census shows that its total population in Cuba was only 1,046. For a detailed analysis of the demographic and economic aspects of the Chinese peon trade, see De La Riva (1978), p. 58, which contains an estimate of some 50,000 Chinese emigrants in the period 1853-1861 and a total of 124,813 of Chinese peons who arrived in Havana in the period 1848-1874. See also De La Riva (1967).
} 
TABLE 1

Sugar Production of Cuba, 1820-1875 (metric tons).

\begin{tabular}{|c|c|c|c|}
\hline Years & Production & Years & Production \\
\hline 1820 & 54,906 & 1848 & 260,463 \\
\hline 1821 & 58,678 & 1849 & 239,128 \\
\hline 1822 & 64,322 & 1850 & 294,952 \\
\hline 1823 & 74,054 & 1851 & 365,843 \\
\hline 1824 & 62,498 & 1852 & 329,905 \\
\hline 1825 & 56,150 & 1853 & 391,247 \\
\hline 1826 & 77,856 & 1854 & 397,713 \\
\hline 1827 & 77,669 & 1855 & 462,968 \\
\hline 1828 & 77,006 & 1856 & 416,141 \\
\hline 1829 & 84,187 & 1857 & 436,030 \\
\hline 1830 & 104,971 & 1858 & 426,274 \\
\hline 1831 & 89,073 & 1859 & 469,263 \\
\hline 1832 & 98,895 & 1860 & 428,769 \\
\hline 1833 & 97,425 & 1861 & 533,800 \\
\hline 1834 & 105,376 & 1862 & 454,758 \\
\hline 1835 & 115,902 & 1863 & 445,693 \\
\hline 1836 & 112,948 & 1864 & 525,372 \\
\hline 1837 & 115,767 & 1865 & 547,364 \\
\hline 1838 & 136,815 & 1866 & 535,641 \\
\hline 1839 & 122,209 & 1867 & 685,814 \\
\hline 1840 & 161,248 & 1868 & 720,250 \\
\hline 1841 & 169,886 & 1869 & 718,745 \\
\hline 1842 & 192,769 & 1870 & 702,974 \\
\hline 1843 & 182,081 & 1871 & 609,660 \\
\hline 1844 & 208,506 & 1872 & 772,068 \\
\hline $1845(*)$ & 98,437 & 1873 & 742,843 \\
\hline 1846 & 205,608 & 1874 & 768,672 \\
\hline 1847 & 267,474 & 1875 & 750,062 \\
\hline
\end{tabular}

Sources: Moreno Fraginals (1978) vol. III, pp. 35-37; Deerr (1949-1950), p. 131 (*) There were two major hurricanes in that year. 
TABLE 2

Arrival of slaves from Africa to the Americas by region of disembarkation, 1844-1867.

\begin{tabular}{|c|c|c|c|c|c|}
\hline Years & Bahia & $\begin{array}{c}\text { Southern } \\
\text { Brazil }\end{array}$ & Cuba & $\begin{array}{c}\text { All other } \\
\text { regions (*) }\end{array}$ & TOTAL \\
\hline 1844 & 6,634 & 19,500 & 10,000 & 130 & 36,264 \\
\hline 1845 & 5,582 & 16,000 & 1,809 & 163 & 23,554 \\
\hline 1846 & 7,354 & 42,500 & 1,000 & & 50,854 \\
\hline 1847 & 10,303 & 49,000 & 1,685 & 300 & 61,288 \\
\hline 1848 & 7,639 & 52,000 & 1,950 & & 61,589 \\
\hline 1849 & 9,788 & 45,980 & 7,400 & 450 & 63,618 \\
\hline 1850 & 9,921 & 19,364 & 3,100 & 2,300 & 34,685 \\
\hline 1851 & 1,885 & 2,159 & 5,000 & 850 & 9,894 \\
\hline 1852 & & 1,058 & 7,000 & & 8,058 \\
\hline 1853 & & & 12,500 & & 12,500 \\
\hline 1854 & & & 11,400 & 239 & 11,639 \\
\hline 1855 & & & 6,408 & 309 & 6,717 \\
\hline 1856 & & & 7,304 & 324 & 7,984 \\
\hline 1857 & & & 10,436 & 1,543 & 11,979 \\
\hline 1858 & & & 15,000 & 2,320 & 17,32 \\
\hline 1859 & & & 25,000 & 5,539 & 30,539 \\
\hline 1860 & & & 21,000 & 3,722 & 24,722 \\
\hline 1861 & & & 13,812 & 2,694 & 16,506 \\
\hline 1862 & & & 10,271 & 3,158 & 13,429 \\
\hline 1863 & & & 3,799 & & 3,799 \\
\hline 1864 & & & 2,353 & & 2,353 \\
\hline 1865 & & & 795 & & 795 \\
\hline 1866 & & & 700 & & 700 \\
\hline 1867 & & & 1,000 & & 1,000 \\
\hline $44-1867$ & 59,106 & 247,881 & 180,722 & 24,041 & 511,750 \\
\hline
\end{tabular}

(*) Region of Pernambuco, 1844-1851, French possessions in the Americas, except 338 to the United States in 1858 and 1,000 to Puerto Rico in the following year. Those who went to French territories were legally considered voluntary immigrants.

Sources: Eltis, "The Direction and Fluctuation of the Transatlantic Slave Trade, 1844-1867" (Unpublished). 
In this period, the character of slavery in the western hemisphere also underwent a major change. Slavery had disappeared in the British West Indies (1834), the Swedish (1847), the French (1848) and the Danish West Indies (1848). In 1863 it also disappeared in the Dutch colonies. More important, of course, was the beginning of the American Civil War and the precarious situation in which slavery was in 1863 in that country. It is clear that the persistence of slavery in the United States was at that time doubtful, and one might think that this had implications for the ideas of Cubans regarding the duration of their own system. However, as reflected in the price data of slaves, Cuban landowners (and elsewhere) did not seem to expect their slave systems to disappear any time soon.

\section{IV}

The information on each of the Cuban slaves for whom we have data from the years 1856, 1859, 1861 and 1863 consists of the year of registration, name of the mill where he or she resided, name, sex, color, age, nationality, characteristics, height, moral character, health, occupation and price. In this analysis we have only focused on certain aspects of the pricing pattern and structure and, therefore, we have not used all the existing information. To achieve the desired homogeneity for comparative purposes, we first divided the sections into four categories based on information on health and occupation: healthy and unskilled $(2,799)$, healthy and skilled (750), sick and unskilled (556) and sick and skilled (115). In most of the analysis, we limited ourselves to using the healthy and unskilled category, which was the largest and allowed the best comparisons with the slave population elsewhere. However, we have made estimates of the premiums for qualified occupations and discounts for ill health. Within these four classes, we divide slaves into four different categories, according to their place of origin and sex: Creole males, African males, Creole women and African women. Calculations were made independent, within these categories, of the prices of slaves of each age and of each year.

Our analysis will be based on two types of calculations. We will first use the prices of the oldest slaves (defined as the eighteen-thirty-nine age group) for each year to examine both the trend in global prices for the period and the difference between men's and women's prices, and between Africans and Creoles. Second, within each year we have calculated the difference between the average price of each age and the price of the best age in that category (for example, Creole males) in that year. Given that the price structures for each of the years were similar, we have averaged four years when examining the price structure for sexes and ages. It should be noted that the use of somewhat different age ranges for the price of older 
age slaves did not alter the results. And the use of specific years or more different schemes to weight these years has not had an important influence on our interpretations of the price pattern either by sex or age.

In the period 1856-1863 the price of slaves varied appreciably, reflecting to a certain extent the variations in the production and price of sugar, as well as in the imports of slaves. The prices of the older male creoles increased by 90 percent between 1856 and 1859: from 668 pesos to 1,271. They then fell a little to 1,163 pesos in 1861 and 914 in 1863 . Even after these declines after the sharp rise in the first three years, the average price of a healthy farm worker in 1863 was still more than a third higher than in 1856. It is clear that despite the increasing number of African and Chinese workers, slave owners were willing to pay higher prices than in the previous decade. In fact, slave prices had peaked in 1859, but even those in 1863 were quite high by historical standards.

These variations in the prices of slaves in Cuba had a parallel in other parts of the Americas, reflecting the global expansion of Europe and its demand for slave-produced goods, in the late 1850s. ${ }^{15}$ In New Orleans, the nominal price of older male farm workers had risen from 697 pesos in 1850 to 1,085 pesos in 1856 , peaking at 1,451 pesos in 1860 . With the start of the civil war, prices dropped to around 1,116 pesos in 1862 , before price inflation in the Confederation and the circumstances of the war limited the possibility of comparing these series. ${ }^{16}$ In Rio Claro (Brazil), the prices of males from fifteen to twenty-nine years of age had risen from 650 millreis in 1850 to 1,700 in 1856 and 2,000 in 1860, and had dropped to 1,860 in 1862 , but did not begin to decrease appreciably until after $1881 .{ }^{17}$ In Vassouras, the average price of slaves and slaves had risen from approximately 550 millreis in 1850 to 1,350 in 1856 and 1,450 in 1860, and

\footnotetext{
${ }^{15}$ The year 1857 witnessed maximum economic activity in the United States and England, but it was also a year of a relatively rapid recovery from a cyclical depression in both economies, although the experience of the United States was different due to the outbreak of the civil war. See the annual estimates in Gallman (1966) and the totals of the national accounts of the United Kingdom (as well as those of Germany and France), published in Mitchell (1975), pp. 781, 782 and 797. In 1857 sugar prices reached the highest level of the period 1824-1863. US Bureau of Census (1975) p. 209. New York daily prices indicate that in October 1857 they reached the highest level in fifty years. Prices indeed fell sharply in November, but in January 1858 they had begun a rapid recovery.

${ }^{16}$ See Kotlikoff (forthcoming).

${ }^{17}$ See Dean, (1976), p. 55.
} 
continues to increase until $1880 .{ }^{18}$ In Rio de Janeiro, the average price of all slaves rose from 320 millreis in 1850 to 874 in 1856 and 1,016 in 1860, falling to 797 in 1866, with no appreciable decrease in this field until the decade of $1880 .{ }^{19}$ In Ponce, Puerto Rico, the sale price of male farm slaves rose from about 400 pesos in 1855 to almost 700 in 1860, before dropping to around 600 in $1865 .^{20}$

Thus, throughout America, the 1850s was a period of rapid increases in slave prices, with some declines, generally in the areas where slavery did not disappear, which began in the early 1860s, but which kept prices in the mid-decade considerably above those of the years before 1850 . Given the importance of production for the expanding European and North American markets, the great similarity of the variations in slave prices observed in the 1850s in the three main remaining slave powers: Cuba, the southern United States and Brazil is not surprising. In none of these cases do the price guidelines suggest that slave owners of the 1850 s and 1860 s (outside of the southern United States) perceived the slave system to be on the verge of collapse and to expect permanent price declines. ${ }^{21}$

In examining the prices of slaves of specific origin and sex from Cuban sugar plantations, some anomalies are evident (see Table 3). In the first place, the prices of the oldest female slaves tended to be 93 percent of those of the male slaves of the same age, both in the case of Creoles and in the case of Africans. ${ }^{22}$ These differences between men and women were somewhat lower than those found in some of the British West Indies, as

\footnotetext{
${ }^{18}$ See Stein (1957), p. 229.

${ }^{19}$ See Carvalho de Mello (1977), p. 50. This work also describes the sharp drop in prices in the 1880 s, given the expectation of abolition. In Campinas, Slenes (1975), p. 253 found a steady rise in men's prices from fourteen to twenty-eight years of age of about 90 percent between 1853 1854 and 1858, after which they remained relatively stable until after 1880.

${ }^{20}$ Curet (forthcoming).

${ }^{21}$ Aimes (1907, p. 268) presents slave price data from 1875 which shows a somewhat confusing pattern, but none of the post- 1860 prices are lower than the pre- 1850 prices. Slave prices could be expected to drop in the mid-1870s after the approval of the Moret Law in 1870, the abolition of slavery in Puerto Rico in 1873, and the announcement by the Spanish Government that the abolition would extend to Cuba as soon as the war ended. At that time there was relatively little sale of slaves, so the figure presented by Aimes would be biased.

${ }^{22}$ It should be noted that the differences between men and women and Creoles and Africans appear smaller in the years when prices were higher than in those years when they were lower, although these variations in differences with the price level are not very big. Table 3 shows an unusual pattern in 1861, when African slaves were priced a higher price than that of the creoles, a phenomenon that until now we have not been able to explain.
} 


\section{well as in the United States. ${ }^{23}$ The fact that these relative prices for Cuban slaves were apparently high so late in the slave era is perhaps surprising}

${ }^{23}$ See Higman (1976) pp. 188-205; Craton, (1975), pp. 249-284, and Fogel and Engerman, (1974b), vol. I, pp. 67-68. On the York estate in 1778, a Jamaica sugar plantation, farmworkers aged twenty-one to forty were appraised at 89 percent of the value of farmworkers of the same age (Gale-Morant Papers, University of Essex Library). Evans (1962), p. 225 presents data on the proportion in the United States between female and male slaves between 1842 and 1860 , which range between 0.75 and 0.93 , with the majority of observations being between 0.85 and 0.89. It is not clear whether Evans' prices refer only to the best age and whether they include skilled slaves. These could explain the fact that the differences are greater than those of Fogel and Engerman, which refer to slaves in the best age, unskilled and healthy. Sharp shows that in the Colombian frontier the best-quality female slave workers in the countryside were priced in 1768 and 1779 at 93 percent of the price of men. Sharp (1976), p. 203. For estimates suggesting that prices by sex were approximately equal, see Palmer's (1981, p. 125) analysis for 1727 and field worker estimates of the Codrington Plantation (in Barbados) for 1775 presented by Bennet (1958), pp. 17-18. However, Galenson (1982), pp. 491-511 presents evidence of the sales of slaves by the Royal African Company in Barbados between 1673 and 1723 that have an average value of the annual proportions between the prices of women and men of approximately 0.85 in the case of slaves sold in the first half of auctions. However, these do not have exact information on the ages of the slaves, and they vary with the duration of the auctions in which those sales were made. See also Galenson (1979), pp. 241-249. An exception to the usual differences between male and female prices in this period is that of the data on Rio de Janeiro presented by Carvalho de Mello (1977) p. 51 for the second half of the 19th century. This author attributes this pattern to the relative weight given to urban skilled occupations and the higher proportion of women in urban areas. The Brazilian pattern presented by Carvalho de Mello differs from that of other sources. In Bahia, in the mid-nineteenth century, domestic slaves were priced above farmworkers but at the best age of both groups, women were between 85 and $99 \%$ of the value of men. Marcilio (1978). In Rio Claro, in a similar period of time, "women sold, on average of three-quarters of the value of men." Dean (1976) p. 58. And in Campinas, between 1853-1854 and 1887, female slaves from fourteen to twenty-eight years old sold for between 60 and 98 percent of the value of male slaves, the difference sharply decreasing in the early 1860 s. Slenes (1975), pp. 252-258. Thus, it is clearly necessary to study further the pattern of prices by sex in Brazil. Regarding slaves sold in Lima between 1560 and 1650, there were years when female slaves were priced at a much higher prices than males, but in general female slaves were sold to slightly higher prices. See Bowser (1974), pp. 342-345. The fact that female slave prices were higher may reflect the urban location of the slave market. Another case in which the prices of female slaves were higher than those of male slaves, in an earlier period and in a different hemisphere, is that of Seville, between 1470 and 1525. See Franco Silva (1979), p. 119. In his description of the transfer of colonial techniques from the Mediterranean to the Atlantic, Verlinden (1970), p. 29 states, however, that "in Spain, female slaves were generally cheaper than male slaves, although in most of Italy the opposite occurred". This author attributes it to the use of slaves in agriculture and industry in Spain, in contrast to the predominance of urban domestic slaves in Italy. In Russia between 1450 and 1725, single adult women were only sold at 73 percent of the price of single men, even though Russian slaves were not generally used in agriculture. Hellie (1982), p. 417.

There are a few more puzzles in the data on Brazil collected by the British Foreign Office in the mid-nineteenth century. Among the new African imports. There were women who sold 20 
given the imminent end of slavery in the southern United States (suggesting an imminent disappearance of slavery in all the New World) and the crucial importance of labour on the sugar plantations. Naturally, if it was expected that the emancipation law would link children over a period of years to the owners of their mothers, as was done in the Moret Law of 1870, as well as in the Brazilian law of that same year, then the decline in the expected value of the slaves could be quite small. ${ }^{24}$ And although there was still an excess of African male slaves in relation to female slaves, it is possible that this difference reflected the patterns of African suppliers, as well as of the demands of the Cuban importers of slaves and therefore does not have to imply that the valuation of the female slaves was lower. ${ }^{25}$

TABLE 3

Average Price of Slaves in the Sugar Plantations of Cuba (in pesos).

\begin{tabular}{lcccc} 
& $\mathbf{1 8 5 6}$ & $\mathbf{1 8 5 9}$ & $\mathbf{1 8 6 1}$ & $\mathbf{1 8 6 3}$ \\
\hline Creole men & 668 & 1,271 & 1,163 & 914 \\
Creole women & 622 & 1,217 & 1,057 & 830 \\
African men & 628 & 1,212 & 1,125 & 809 \\
African women & 574 & 1,152 & 1,073 & 725 \\
\hline
\end{tabular}

Sources: See text.

percent less than men, but there are no differences between "ladinos". And the most curious thing is that recently imported slaves were sold at higher prices than those of Ladinos.

${ }^{24}$ Fogel and Engerman (1974a), pp. 377-401. It is also possible that Cubans envisioned a victorious and independent South and the continuation of slavery even until 1863 and, therefore, did not perceive its weakening as an institution.

${ }^{25}$ See Klein, (1979) pp. 228-251, for the argument that the sex ratio of imported slaves was influenced by African demands. 
Similarly, the prices of Africans of both sexes tended to be 94 percent that of the Creoles of the same sex. ${ }^{26}$ Although it is not possible to determine exactly when these Africans were imported and, therefore, to know if they were overworked, the price differences seem smaller than those previously observed in Jamaica. ${ }^{27}$ It is possible that the smaller difference in Cuba reflects the fact that most of the plantations in the sample were founded after 1820, mainly with African slaves and that, therefore, the majority of registered Africans had been in Cuba for some years, as well as the fact that there were few Creole slaves who could belong to a generation after the second generation born in Cuba.

\section{VI}

Figures 1 and 2 present data on the price structures by age and sex of the Creoles and the Africans. They are shown separately because it seems better to compare them given the importance that the owners of the slaves attached to their place of origin in the valuation as well as to avoid difficulties in making comparisons outside the older age groups. In the case of creoles, there are a large number of slaves below the best ages and, as expected, there are few over forty years of age. In the case of Africans, the pattern is reversed: there are few under eighteen and many over forty.

\footnotetext{
${ }^{26}$ In the case of the domestic slaves of Bahia from thirty-four to thirty-five years of the period 1838-1882, the African slaves were sold at a premium of $1 / 8$ (women) to $1 / 4$ (men) higher than that of the Brazilian slaves. Marcilio, (1978) p. 94. However, this result is based on a small sample and may be influenced by a time trend in slave values. Dean (1976) p. 58, indicates that no distinctions were made between Africans and creole slaves. In Lima in 1560-1650, the bozales tended to be sold at a higher price than the creoles. Bowser, (1974), pp. 342-343.

${ }^{27}$ See Craton (1975) p. 278. This comparison strictly refers to "new Africans" and "overworked slaves". In general, in the case of the British West Indies, the debates of the Parliamentary Papers prior to the disappearance of the slave trade suggest that creoles were priced at a higher price than imported slaves, in an order of magnitude similar to that which appears in Craton. At the York estate in 1778 (see footnote 23), African slaves were sold for three-quarters of the value of the Creoles.
} 


\section{FIGURE 1}

Average Prices Relative to Age and Sex: Creole, Healthy, and Unskilled Slaves.

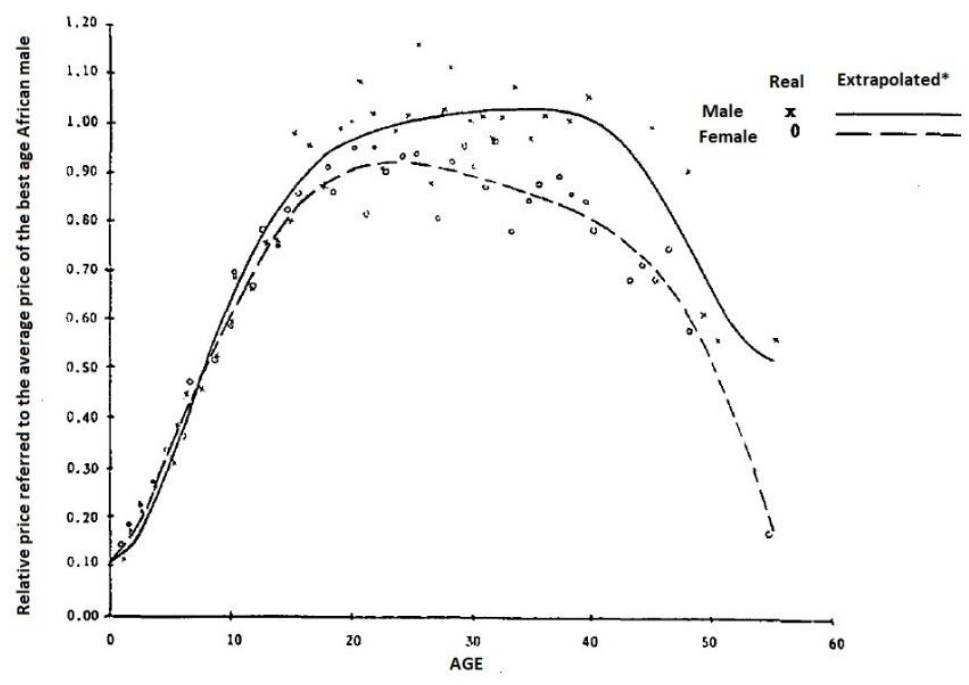

*Extrapolated from a sixth-grade polynomial obtained from the average of observations.

FIGURE 2

Average Prices Relative to Age and Sex: African Slaves, Healthy and Unskilled.

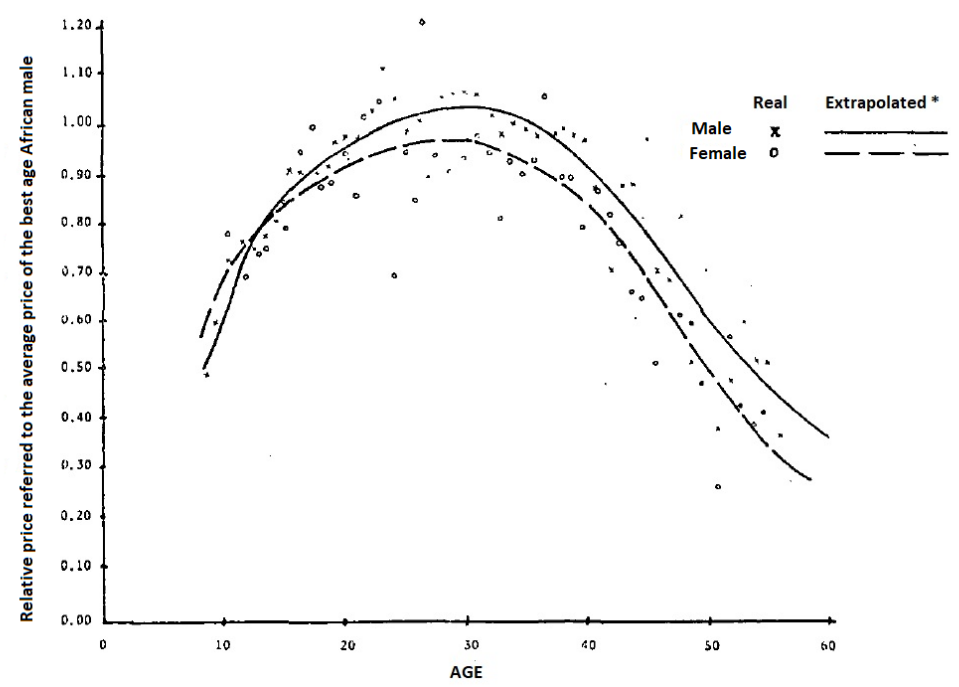

*Extrapolated from a sixth-grade polynomial obtained from the average of observations. 
Male prices, both Creole and African, peaked at approximately thirty years of age, a pattern similar to that observed in the case of American slaves. In Cuba, the maximum price of Creoles is lower than that of Africans and the decline after the age of thirty is less pronounced. In the case of Africans, among whom there were more older slaves, the prices of men fell to approximately half the maximum level when they were about fifty-five years old, a pattern similar again to that found among male slaves of the United States. As in that country, the female slaves reached a maximum a few years before the male slaves, between twenty and twenty-five years of age. The pattern of price increases for Cuban Creoles with age, is similar in one respect to the pattern found among American slaves: female slave prices rise relatively earlier than those of the male slaves and, therefore the difference between prices of female slaves and those of creole slaves are higher before their twenties than later. ${ }^{28}$ In the case of Africans, it seems that the rate of decline in female slave prices is somewhat higher than that of the male slaves after the best ages, a sex pattern similar to that of the United States, although not as marked.

Thus, in general, the price patterns for sex and age of Cuban slaves do not differ dramatically from those of slaves in the United States, Jamaica and Brazil. ${ }^{29}$ Prices peaked at approximately the same ages, and the patterns of relative increase and decrease by sex are somewhat similar, reflecting the relatively earlier physical maturity of female slaves. Lacking adequate data on Cuban fertility patterns, we cannot decompose the value of female slaves in proportions due to their work in the fields and their ability to have children and, therefore, we cannot adequately explain the differences between the declining rates of male slaves and female slaves. ${ }^{30}$ However, it is surprising that, despite the apparent differences between fertility and mortality patterns, maximum slave prices were reached at approximately similar ages in both the United States and Cuba. ${ }^{31}$

${ }^{28}$ A similar pattern is also observed in the Campinas data presented by Slenes (1975) p. 260, and in the Colombian data presented by Sharp (1976) p. 203.

${ }^{29}$ See Higman (1976) pp. 198-205, and Slenes (1975) pp. 252-262. In Seville, in the late Middle Ages, prices peaked in ages sixteen to twenty-five, and fell to half the maximum level in the age range forty-one to sixty. These data are not differentiated by sex and there are no estimates of slaves under the age of ten. Silva, (1979) pp. 116-118.

${ }^{30}$ See Fogel and Engerman, (1974b) vol. I, pp. 78-86, for such a breakdown for the United States. Even given high fertility and favorable mortality experience, the value of the ability to have children was at most about 20 percent of the value of first quality field workers. It could be expected that at that time, the difference between the raising of children and the global productivity of women was less in Cuba than in the United States.

${ }^{31}$ It is difficult to choose based on the work of Slenes at precise ages when women's prices were highest, but it seems that they ranged from twenty to thirty years of age. Slenes (1975), p. 260. Regarding eighteenth-century Colombia, the Sharp data suggests that the maximum price was 
The data on the price pattern by age and sex of Cuban Creoles allows some comparisons to be made with slaves in the United States, as well as providing information on the expectations that slave owners had about the future. The positive price of a child, who did not start working in the fields until after a decade and whose expected future earnings had to be discounted to take into account how long it took to be positive, tells us a lot about the economic and political expectations of landowners about the future of the institution of slavery. It should be noted, therefore, that prices in the zero-to-one-year age category were on average about 10 percent of the prices of the best ages, not unlike those observed in the United States around $1850 .{ }^{32}$ And, as far as males are concerned, half the price of the best ages was reached at about nine years old, while in the United States it was reached one year later (and at least in a Jamaican plantation at approximately the same age). ${ }^{33}$ Thus, to the extent that we can use data on the age structure of slave prices to deduce physical productivity and/or the expectations of landowners, it is the similarity of the patterns of the United States and Cuba in mid-nineteenth century that is so amazing. In addition, in many respects Cuba's slave price pattern by age and sex does not differ much from that of Jamaica (and probably from the British West Indies and other slave colonies) of earlier decades.

\section{VII}

There are some data sources from earlier periods that provide interesting comparisons with the patterns described from the mid-nineteenth century. Ward Barrett (1970) has presented some data on the price relationships by

reached somewhat earlier, between the ages of fifteen and nineteen, but women's prices declined slightly between the nineteen and thirty-nine years of age. See Sharp (1976) p. 203.

${ }^{32}$ In the case of Colombia, Sharp (1976 p, 203) estimates that the prices of children were between 5 and 10 percent of the maximum slave price levels, while in the case of Barbados, Bennett (Bondsmen and Bishops, pages 17-18) estimates that the prices of children were about 8 percent of the maximum price for farmworkers. Higman (1976), p. 205 presents a similar pattern in the case of Jamaica. See also Ward (1978) p. 203. In Venezuela, in the slave price schedule used to set the prices of manumissions between 1821 and 1854, there were eight-day-old slaves that were sold at a sixth of the price of first-class and high-quality slaves two year olds that sold for a third of the price and at eight years for half the price of the highest priced slaves. These data are not differentiated by sex. See Lombardi, (1971), p. 157. In the case of Rio Claro, Dean (1976), p. 58 points out that "two-year-olds sold for approximately one tenth of the price of adults."

${ }^{33}$ Higman, (1976) p. 205. As for Colombia, the price of men was half the maximum price in the 8 to 10 years of age group (Sharp 1976, p. 203), while in Barbados it was between 7 and 13 years of age (Bennett (1958) pp. 17-18). In Rio Claro, eight-year-olds were priced at half the price of adults. Dean (1976) p. 58. 
age and sex according to the place of origin of the slaves of a Mexican sugar plantation corresponding to several years between 1596 and 1754 . Although it is difficult to make comparisons, given that the number of slaves is small and at no time were there Africans and Creoles of a comparable age, it seems that the prices of male slaves did not reach a maximum until they were about twenty-five years old. Prices were half the maximum price between the ages of ten and fifteen and did not begin to drop until after forty. In the eighteenth century, the top two prices for female slaves tended to be a lower proportion of female slave prices than in nineteenth-century Cuba, although at younger ages the prices of both seemed to be quite similar. However, these comparisons are based on a small number of observations, although they may be useful as an indication. ${ }^{34}$

Another example of a price pattern, somewhat similar to that of Cuba by age and sex, is also observed in a series of slaves sold to the Portuguese in 1519-1520. In the better ages (eighteen to twenty-seven), female slaves were sold for about 97 percent of the price of male slaves. In the younger ages, female slaves tended to be priced at higher prices than male slaves, although after the older ages their relative value decreased slightly. ${ }^{35}$

Other comparisons of slave prices patterns can also be made. In the ancient Near East, in the neo-Babylonian period, the price of female slaves was between two-thirds and three-quarters of the price of male slaves. ${ }^{36}$ In Delphi, in the period 201-1 B.C., adult female slaves paid a price for freedom that was approximately 80 percent that of male slaves. ${ }^{37} \mathrm{In}$ Diocletian's Edict (A.D. 301), the maximum price of female slaves from sixteen to forty years was five-sixths of that of male slaves. The edict also gives the maximums of different ages, shown in Table 4, in relation to the maximum price of each sex.

\footnotetext{
${ }^{34}$ Barrett, (1970), pp. 83, 97-98.

${ }^{35}$ Saunders, (1982), pp. 19-27. The ratio between the prices of males from three to seven years of age and the maximum prices was approximately $30 \%$; between eight and twelve years it was approximately 54 percent, and increased to approximately 80 percent between thirteen and seventeen years, decreasing to approximately 55 percent between thirty-three and thirty-seven, and $25 \%$ between thirty-eight and forty-two (which is the oldest age group that appears).

${ }^{36}$ Mendelsohn (1949), p. 117.

${ }^{37}$ Hopkins (1978), p. 159. There are some slave prices, by age and sex, in the case of Egypt - in the Greek and Roman periods, but they are not enough to make detailed comparisons of any period. Biezunska-Malowist (1977), Annexe. The same occurs in the case of the prices presented in Westermann (1955), pp. 14-15, 71-72 y 100-101.
} 
TABLE 4

Maximum price of slaves according to age and sex (Diocletian's Edict, A.D. 301).

\begin{tabular}{|l|c|c|}
\hline \multicolumn{1}{|c|}{ Age } & Men & Women \\
\hline Younger than 8 & 50,0 & 40,0 \\
\hline From 8 to 16 & 66,7 & 80,0 \\
\hline From 40 to 60 & 83,3 & 80,0 \\
\hline Older than 60 & 50,0 & 40,0 \\
\hline
\end{tabular}

Sources: Weidemann (1981), p. 105.

Note that in Diocletian's Edict, female slave prices rose relatively faster between the ages of ten and fifteen than those of slaves, while they also fell faster in older ages, patterns consistent with those in Cuba. and the United States centuries later.

Finally, in Leviticus (XXVII: 3-7) there is a more marked difference between male and female slaves, since females were only priced at 60 percent of the price of male slaves (a difference not very different from those found currently in the United States for full-time workers). ${ }^{38}$ Compared to adult slaves (twenties-sixties), slaves from zero to five years were priced at approximately 10 percent, those from five to twenty years at 40 percent, and those over sixty at 30 percent, while the price ratios of female slaves (compared to adult female slaves) were 10\%, $331 / 3 \%$, and $331 / 3 \%$, respectively. Note that in this case the prices of slaves increase faster between ten and twenty years than that of slaves and their prices fall faster when they are old.

\section{VIII}

In this article we do not present a detailed examination of some other issues that can be analysed with this data set. Thus, for example, the

\footnotetext{
${ }^{38}$ However, these probably refer to uncapitalized annual income values.
} 
relationships between the sexes, age, origin, health, and colour are not examined. We do, however, wish to briefly present some information on the qualification patterns of male slaves and their possible variations over time. The premium for skilled and semi-skilled slaves was, on average, 10 to 20 percent; the frequency of skilled occupations tended to increase with age, and at a given age the percentage of skilled Creoles was higher than that of Africans. However, given the divergences between the age structure of Creoles and that of Africans during this period, there were more Africans with skilled occupations than Creoles, even among highly skilled machinists.

However, the period studied is a period of transition in the technology of sugar production and in the character and meaning of some occupations. Until about 1840 , sugar technology was relatively simple, and skills were readily available, limiting the magnitude of the premium for skilled workers. ${ }^{39}$ However, in the middle of the century, technical development accelerated, and the adoption of new and expensive machinery spread. To operate these machines, plantation owners used three sources of labour: wage labourers, Chinese contract labour, and trained slaves to perform skilled labour. In general, these three solutions to the problem of work were followed, and the existence of these possibilities must have limited the number and estimated bonuses of qualified slaves. Thus, as long as no further studies are conducted, it is difficult to know whether the estimated skilled slave premiums for 1856-1863 can be applied to earlier and later periods.

\section{IX}

From this set of data on prices for age and sex of Cuba for the years between 1856 and 1863, several conclusions can be deduced. There is clear evidence that the Cuban slave owner of that time did not see an immediate threat to the long-term value of their main economic asset and that the last years of the 1850 s were a period in which the returns on slave ownership were high throughout America. Regarding the price structure, in the period of time covered it seems that there were relatively small price differences between Africans and Creoles and between men and women among those who worked in the field. ${ }^{40}$

\footnotetext{
${ }^{39}$ In our data series, for example, the most frequent skill listed is "carretero", an occupation that required more capacity than a farm worker, but which was easily learned and therefore only had a relatively small premium with respect to field workers.

${ }^{40}$ This basic pattern does not vary even if differences between skills and health are taken into account.
} 
Of greater interest are the approximate similarities observed between the price structures by sex and age of these Cuban slaves in the midnineteenth century and those of slaves from other places and times. These broad trends existed despite the marked differences between the social, economic, and demographic conditions of these slave societies. These differences - between expected mortality, harvests, the use of slave labour, and the relative amount of free and slave labour - might be expected to have generated more pronounced differences in slave price structures. Therefore, even the widest similarities raise questions about the general physiological development and productive capacity of slave (and free) labour, as well as the nature of the calculations made by slave owners in different epochs. Although perhaps not too many conclusions should be drawn from such general comparisons, they do provide a further indication of the usefulness of data on slave prices for the analysis of historical questions.

Online appendix with the data of this article: https://doi.org/10.21950/D4YBYQ

\section{References}

Aimes, Hubert H. (1907) A History of Slavery in Cuba, 1511-1868, New York.

BARRETt, Ward (1970) The Sugar Hacienda of the Marqueses del Valle, Minneapolis.

Biezunska-Malowist, Iza (1977) L'Esclavage dans L'Egypte Greco-Romaine, Seconde

Partie, Periode Romaine, Varsaw.

BenNetT, Harry J. (1958) Bondsmen and Bishops, Berkeley.

Bowser, Frederick P. (1974) The African Slave in Colonial Peru, 1524-1650, Stanford, 1974.

Carvalho de Mello, Pedro (1977) «The Economics of Labour in Brazilian Coffee

Plantations, 1850-1880», $\mathrm{PhD}$ thesis, University of Chicago.

El Centro de Estadística (1864) Notícias estadísticas de la isla de Cuba en 1862, La Habana.

ConwIN, Arthur F. (1967) Spain and the Abolition of Slavery in Cuba, 1817-1886, Austin, Texas.

Craton, Michael (1975) «Jamaican Slavery», in Stanley L. Engerman and Eugene D.

Genovese, eds., Race and Slavery in the Western Hemisphere, Princeton.

CuRET, José «About Slavery and the Order of Things: Puerto Rico, 1845-1873», in Manuel

Moreno Fraginals, Frank Moya Pons and Stanley L. Engerman, (eds.) Slavery and Free

Labour in the Spanish-Speaking Caribbean, Cuba, Puerto Rico, and the Dominican Republic in the Late Nineteenth Century, (forthcoming).

Curtin, Philip D. (1969) The Atlantic Slave Trade: A Census, Madison. 
De la Riva, Juan (1978) El barracón: esclavitud y capitalismo en Cuba, Barcelona.

De la Riva Juan (1976) Para la historia de las gentes sin historia, Barcelona.

DeAn, Warren (1976) Rio Claro. A Brazilian Plantation System, 1820-1920, Stanford.

DeERr, Noel (1949-1950) The History of Sugar, London.

Eltis, David (1979) «The Direction and Fluctuation of the Atlantic Slave Trade, 18211843: A Revision of the 1845 Parliamentary Paper, » in Henry A. Gemery and Jan S. Hogendorn (eds.), The Uncommon Market, Nueva York.

ELtis, David «The Direction and Fluctuation of the Transatlantic Slave Trade, 1844-1867», (unpublished).

ELy, Roland T. (1961) Cuban Merchants of the 19th Century, Bogota.

Evans, Robert (1962) «The Economics of American Negro Slavery», UniversitiesNational Bureau Committee for Economic Research, Aspects of Labour Economics, Princeton.

Fogel, Robert W. and Engerman, Stanley L. (1974a) «Philanthropy at Bargain Prices: Notes on the Economics of Gradual Emancipation», Journal of Legal Studies, III, June.

Fogel, Robert W. and Engerman, Stanley L. (1974b) Time on the Cross, vol. I. Boston.

Franco Silva, Alfonso (1979) La esclavitud en Sevilla y su tierra a fines de la Edad Media, Seville.

Galenson, David W., (1979) «The Slave Trade to the English West Indies, 1673-1724», Economic History Review, XXXII, May.

Galenson, David W. (1982) «The Atlantic Slave Trade and the Barbados Market, 16731723», Journal of Economic History, XLII, September.

Gallman, Robert E. (1966), «Gross National Product in the United States, 1834-1909», in Dorothy S. Brady (ed.), Output, Employment, and Productivity in the United States After 1800, New York.

Guerra y SANCHEZ, Ramiro (1964) Sugar and Society in the Caribbean, New Haven.

HeLlie, Richard (1982) Slavery in Russia, 1450-1725, Chicago.

Higman, Barry W. (1976), Slave Population and Economy in Jamaica, 1807-1834, Cambridge.

Hopkins, Keith (1978) Conquerors and Slaves, Cambridge.

KIPLE, Kenneth F. (1976) Blacks in Colonial Cuba, 1774-1899, Gainesville.

KLEIN, Herbert S. (1967) Slavery in the Americas, Chicago.

KLEIn, Herbert S. (1979) The Middle Passage: Comparative Studies in the Atlantic Slave Trade, Princeton.

KNight, Franklin W. (1970) Slave Society in Cuba during the Nineteenth Century, Madison.

Kotlikoff, Lawrence J. "A Quantitative Description of the New Orleans Slave Market, 1804 to $1862 »$, in Robert W. Fogel and Stanley L. Engerman, (eds.) Without Consent or Contract, vol. 2 (forthcoming).

Lombard, John V. (1971) The Decline and Abolition of Negro Slavery in Venezuela, 18201854, Westport.

Marcilio, Maria Luiza (1978) «The Price of Slaves in XIXth Century Brazil: A Quantitative Analysis of the Registration of Slave Sales in Bahia», in Studi in Memoria di Federico Melis, vol. 5, pp. 83-97.

Mendelsohn, Isaac (1949) Slavery in the Ancient Near East, Nueva York.

Mitchell, Brian R. (1975) European Historical Statistics, 1750-1970, London.

Moreno Fraginals, Manuel (1978) El Ingenio, 3 vols., Havana.

Moreno Fraginals, Manuel (1976) The Sugarmill, New York. 
Moreno Fraginals, Manuel (1977) «Africa in Cuba: A Quantitative Analysis of the African Population in the Island of Cuba», in Vera Rubin and Arthur Tuden, (eds.), Comparative Perspectives on Slavery in New World Plantation Societies, New York.

Murray, David (1980) Odious Commerce, Cambridge.

ORTIZ, Fernando (1975) The Black Slaves, 2 ed., Havana.

Ortiz, Fernando (1947) Cuban Counter Point: Tobacco and Sugar, trans. by Harriet de Onis, New York.

Palmer, Colin (1981) Human Cargoes, Urbana.

Saunders, A.C. de C.M. (1982) A Social History of Black Slaves and Freedman in Portugal, 1441-1555, Cambridge.

ScotT, Rebecca J. (1981) «Slave Emancipation and the Transition to Free Labour in Cuba 1868-1895» unpublished doctoral thesis, Princeton University.

SHARP, William F. (1976) Slavery on the Spanish Frontier, Norman.

SLENES, Robert W. (1975) «The Demography and Economics of Brazilian Slaves, 1850$1888 », \mathrm{PhD}$ thesis, Stanford University.

Stein, Stanley J. (1957) Vassouras. A Brazilian Coffee County, 1850-1900, Cambridge, MA.

U. S. Bureau of the Census, (1975) Historical Statistics of the United States, Colonial Times to 1970. Washington.

VerLINDEn, Charles (1970) The Beginnings of Modern Colonization, Ithaca.

WARD, J. R. (1978) «The Profitability of Sugar Planting in the British West Indies, 16501834, » Economic History Review, May.

WeIdemann, Thomas (1981) Greek and Roman Slavery, Baltimore.

Westermann, William L. (1955) The Slave Systems of Greek and Rom.an Antiquity, Philadelphia. 


\section{APPENDIX \\ NOTES ON DATA}

The general characteristics of slaves that were regularly observed in the appraisals that we have used were: name, colour, sex, age, nationality, special features, height, moral character (including running away), health, occupation, general remarks and price. All these characteristics require some explanation.

Name: These were the Christian / Spanish names given to slaves when they born in Cuba or when they arrived from Africa. It was forbidden to call Africans by their native African name. Whenever there were several with the same name in the same population, they were numbered: for example, Jose uno, Jose dos, Jose tres, etc.

Colour: Slaves were described as black or brown (negros or pardos).

Age: Even when there were age records, such as when slaves were born on the plantation, age was always a matter of dispute. Therefore, the concept of age should not be understood in a purely chronological way as the number of years lived since birth, but also as an estimate of the physical capacity assumed at the time of the appraisal and in the future. Wellpreserved older people appear to have younger than chronological ages, and vice versa. Age was calculated by slave experts and estimated each time they were appraised or sold. As a general rule, there should be a relationship between chronological and assigned age, although we have found some examples of "aging" very quickly.

Nation: This term was used, throughout Latin America, to designate the place of origin of black slaves. Those born in Cuba were creoles. Africans were classified according to a tribal nomenclature that was very clear and well defined for that time even though it is not always understandable today. For example, when they wrote Congo, they were not referring to the large number of nations and cultures that now inhabit that region, but rather they designated some population that had a specific language and culture that we do not know today. Sugar planters have been shown to prefer slaves in some African nations and reject slaves in others, making the nation a factor in slave pricing.

Specific features: They generally referred to tribal marks, filed teeth and general dental condition, scars, etc. Sometimes physical defects are included: lame, one-eyed, blind, one-armed, etc.

Height: This was not always recorded. Sometimes it was indicated in general terms (high, low, medium, etc.); others were indicated exactly in Spanish feet and inches (Spanish foot $=0.283$ meters). 
Moral character: These are moral defects, according to the standards of the slave owners. The most frequent were fugitive, drunk and thief.

Health: This was designated according to a special nomenclature by the doctors who examined the slaves and, in many cases,, it is difficult to find the corresponding terms in the current medical terminology.

Occupation: This is generally the most important occupation of the slave on the plantation. When there is no clear occupation, nothing was noted or simply appeared as a campo (field worker).

General remarks: These vary considerably. They generally refer to physical defects that, as we said earlier, are sometimes included in "specific features." Some refer to legal status: for example, "coartado" (slave who has paid his master a partial sum to obtain his freedom) or emancipated. Sometimes references are made to where the slaves were: for example, "in the hospital." 